\title{
RANCANG BANGUN ALAT PEMOTONG PANTIAW
}

\author{
Yuliyanto $^{1}$, Erwanto ${ }^{2}$, Gandis Sarahwikan Heyka ${ }^{3}$,Novan Febrian ${ }^{4}$, Syafira Qintasia ${ }^{5}$ \\ 1,2,3,4,5 Jurusan Teknik Mesin - Politeknik Manufaktur Negeri Bangka Belitung \\ Kawasan Industri Airkantung Sungailiat-Bangka, 33211 \\ Telp.0717-93586, Fax.0717-93585, belzanyuliyanto@yahoo.com,
}

\begin{abstract}
Pantiaw is one of the traditional dish made from rice flour served with fish meat grinder and other ingredients. The design of this pantiaw cutting tool uses a press system using a lever. Based on the survey that has been done at the residence of mrs. Yuli, pantiaw produce $8 \mathrm{~kg}$ daily. The obstacle faced by yuli mother at this time is the process of cutting pantiaw still using scissors or knives sliced one by one. So that takes longer time is 45 minutes to 1 hour. The purpose of making this pantiaw cutting tool is to cut the pantiaw uniformly in a single process, increasing the production capacity and the tool is easy to move around. The results of the pantiaw cutter test resulted in uniform pieces of pantiaw in one press / process. Capacity $0.5 \mathrm{~kg}$ pantiaw processing with 30 seconds.
\end{abstract}

Keywords: Pantiaw, Production, uniform shape

\begin{abstract}
Abstrak
Pantiaw adalah salah satu sajian tradisional yang terbuat dari tepung beras yang disajikan dengan gilingan daging ikan dan bahan lainnya. Rancangan alat pemotong pantiaw ini menggunakan system tekan dengan tuas. Berdasarkan survei yang telah dilakukan di kediaman ibu yuli yang kesehariannya memproduksi pantiaw bahwa dalam 1 hari ibu yuli memproduksi 8 kg pantiaw. Kendala yang dihadapi ibu yuli saat ini adalah proses pemotongan pantiaw masih menggunakan gunting atau pisau yang diiris satu persatu. Sehinga waktu yang dibutuhkan lebih lama yaitu 45 menit sampai 1jam. Tujuan pembuatan alat pemotong pantiaw ini adalah dapat memotong pantiaw dengan seragam dalam satu kali proses, meningkatkan kapasitas produksi dan alat ini mudah dipindah-pindahkan. Hasil uji coba alat pemotong pantiaw menghasilkan potongan pantiaw yang seragam dalam satu kali penekanan/proses. Kapasitas pantiaw $0,5 \mathrm{~kg}$ perproses dengan waktu 30 detik.
\end{abstract}

Kata Kunci: Pantiaw, Produksi, seragam

\section{PENDAHULUAN}

Provinsi Bangka Belitung yang terkenal dengan keeksotisan alam dan budayanya juga memiliki wisata kuliner yang sangat spesial. Makanan di Pulau Bangka memiliki kekhasan tersendiri dalam hal citarasa Nusantara. Makanan tradisional adalah warisan budaya yang mengandung kearifan lokal yang patut dilestarikan. Provinsi Bangka Belitung terkenal dengan penghasil lada terbaik serta penambangan timah. Propinsi Bangka Belitung juga dikelilingi oleh laut yang memiliki banyak jenis ikan yang bisa dimakan dan diolah menjadi makanan.

Salah satu makanan tradisional Bangka Belitung yang paling populer adalah pantiaw. Pantiaw merupakan salah satu jenis makanan penganti nasi karena terbuat dari tepung beras. Biasanya pantiaw bisa ditemui di warung-warung kecil di pingir jalan dan pada acara-acara pernikahan dan kenduri. Makanan ini sudah terbukti berhasil menyabet Best Business Plan dengan judul 'Pantiaw Ubi Instan' dalam Jambore HIPMI Perguruan Tinggi se-Asean di Universitas Telkom Bandung [1].

Penyajian pantiaw ini biasanya disertai dihidangkan dengan tumbukan atau gilingan ikan (umunya ikan tanggiri) dan kemudian disiram dengan kuah kaldu ikan yang gurih dan sedap, dan ditaburi toge, daun seledri, bawang goring dan perasan jeruk limau [2]. 


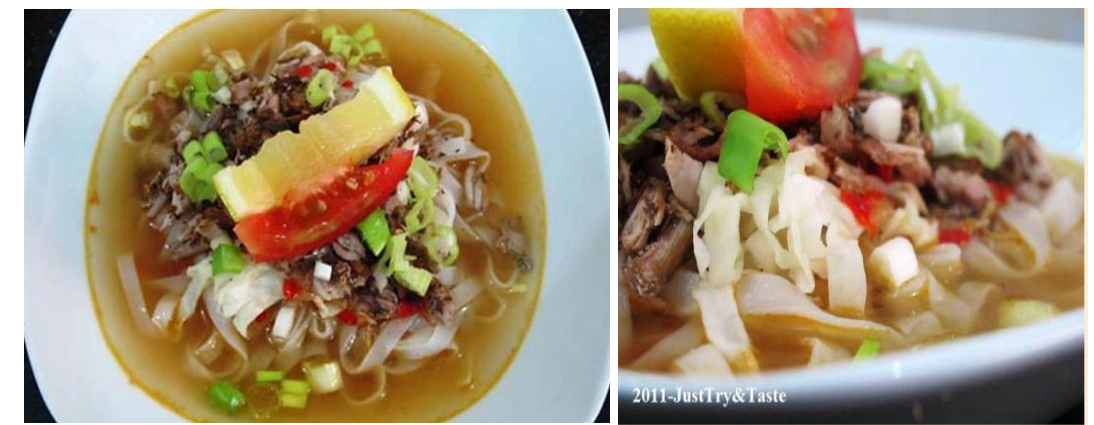

Gambar 1. Pantiaw [1]

\section{METODE PENELITIAN}

\subsection{Tahapan Penelitian}

Pelaksanaan penelitian dilakukan dengan beberapa tahap yang digunakan untuk pedoman penelitian, langkah awal dimulai dari studi-studi literatur yang didapat dari jurnal ilmiah. internet, handbook, text book, manual book. Selanjutnya data-data studi literature dipelajari dan dijadikan referensi untuk melakukan penelitian. Uraian langkah-langkah tersebut tertuang pada diagram alir di gambar 2.

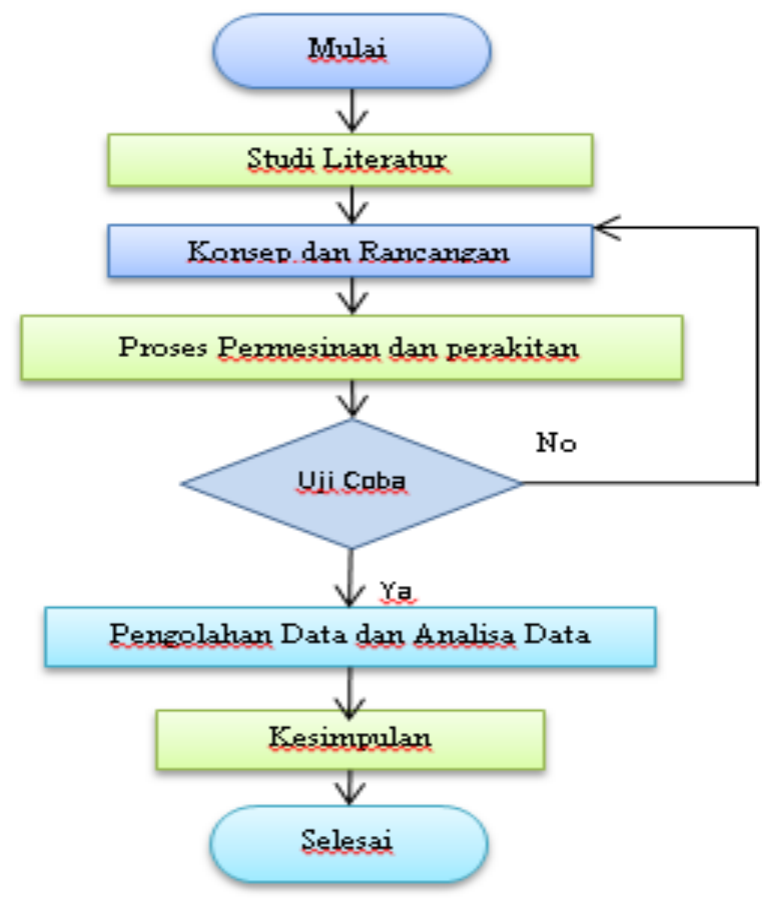

Gambar 2. Diagram Alir Penelitian

\subsection{Konsep dan Perancangan}

Pada tahap ini bertujuan untuk pembuatan konsep dan perancangan alat yang dilakukan dengan menganalisa konstruksi alat yang akan dibuat, sehingga dapat diperoleh alternatif yang akan dipilih berdasarkan target yang ingin dicapai sesuai dengan data-data yang diperoleh dari hasil pengumpulan data baik melalui buku maupun survei yang dilakukan.

Perancangan alat yang dilakukan dengan melihat kebutuhan alat yang dilakukan melaui survei lapangan dan studi pustaka, serta menganalisis alat tersebut sesuai dengan kebutuhan bahan-bahan yang diperlukan untuk membuatan alat dengan proses perhitungan. .yang diperlukan dalam kehidupan masyarakat sehingga dengan adanya alat tersebut dapat membantu masyarakat dalam melakukan pemotongan pantiaw. 
Dalam melakukan perancangan mesin, baiknya mengetahui proses permesinan yang dilakukan sehingga hasil yang didapatkan lebih maksimal dan sebaiknya menggunakan metode perancangan, sehingga dapat diketahui sejauh mana perkembangan permesinan pada saat ini [3]

Alat pemotong pantiaw ini dirancang karena adanya kebutuhan dalam proses pemotongan pantiaw. Dalam melakukan perancangan alat ini [4], berikut merupakan tahap proses yang harus dilalui dalam mengkonsep :

- Penjelasan Masalah

Konsep alat pemotong pantiaw yang digunakan adalah menggunakan sistem tekan dari atas dan dibagian bawah terdapat mata potong. Proses pemotongan dalam satu kali proses dapat memotong pantiaw dengan kapasitas $1 \mathrm{~kg}$ menjadi beberapa bagian dengan masing-masing lebar pantiaw $7 \mathrm{~mm}$.

- Pemilihan Konsep

Terdapat beberapa kriteria desain dalam memutuskan pemilihan konsep untuk mencapai tujuan perancangan. Secara umum kriteria ini dikelompokkan menjadi tiga macam, yaitu kriteria must, want, dan wish [5] [6]. Berikut merupakan tiga kriteria tersebut dalam pemilihan konsep perancangan alat pemotong pantiaw.

1. Kriteria Must, yaitu kriteria yang harus dipenuhi dalam perancangan. Kriteria must dalam pemilihan konsep perancangan alat pemotong pantiaw adalah :

a. Mampu memotong seragam

b. Hasil adonan pantiaw yang telah terpotong dapat otomatis jatuh kedalam wadah dan tidak rusak.

c. Aman dalam penggunaan alat.

d. Kuat

e. Tahan karat

2. Kriteria Want, yaitu kriteria yang diinginkan ada pada proses perancangan.

a. Harga ekonomis

b. Mudah dalam pengoprasian

c. Mudah dalam perawatan

d. Proses produksi alat mudah

e. Kriteria Wish, yaitu kriteria yang diharapkan ada pada proses perancangan.

f. Mudah dalam pengoprasian

g. perawatan mudah

Berdasarkan permasalahan yang ada maka dirancanglah sebuah alat pemotong pantiaw dengan sistem tekan secara manual.

\subsection{Evaluasi}

Evaluasi setelah hasil uji coba alat dilakukan untuk menyediakan informasi tentang sejauh mana keberhasilan alat telah tercapai sesuai dengan konsep yang telah dibuat, serta bagaimana hasil dari uji coba bila dibandingkan dengan hasil alat yang ingin diperoleh. Evaluasi dilakukan dengan menggunakan data-data dari hasil uji coba alat. Gambar rancangan serta hasil pembuatan mesin ditunjukkan pada Gambar 3. 


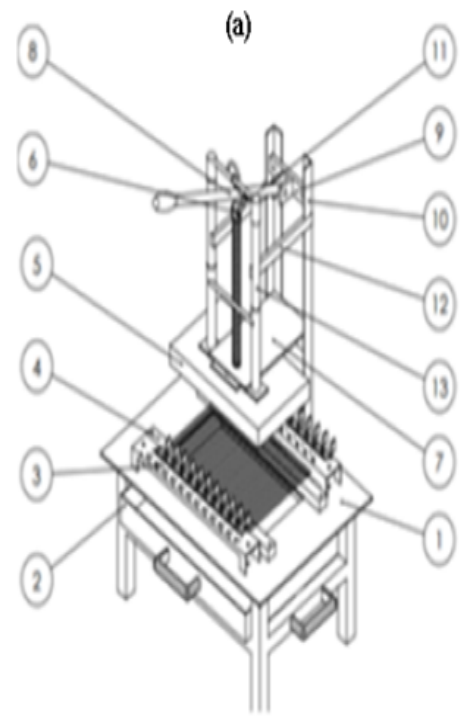

Keterangan:

1. Landasan Kawat pemotong

2. Wadah Penampungan.

3. Pengatur kekencangan Kawat

4. Pelat dudukan kawat

5. Plastik penekan pantiaw

6. pegas penekan

7. Dudukan pegas penekan

8. Pengarah

9. engsel tuas penekan

10. tiang penyanga

11. engsel

12. rangka penekan

13. pelat rangka penekan

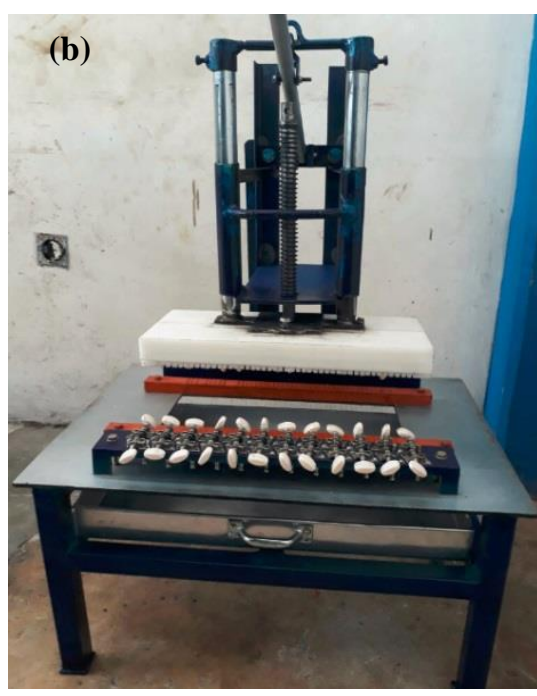

Gambar 3.(a). Gambar rancangan (b). Hasil Pembuatan Mesin

\section{HASIL DAN PEMBAHASAN}

\subsection{HASIL PENGUJIAN}

Pada tahapan ini dilakukan uji coba alat pemotong pantiaw dengan bahan yang digunakan merupakan adonan pantiaw gulungan. Pengujian dilakukan sebanyak 3 kali dan dirata-ratakan. Hasil uji coba dapat dilihat pada tabel 1.

Tabel 1 Hasil Uji coba

\begin{tabular}{cll}
\hline WAKTU & ADONAN & \multicolumn{1}{c}{ KETERANGAN } \\
\hline $\mathbf{3 0}$ Detik & $0,25 \mathrm{Kg}$ & $\begin{array}{l}\text { Adonan terpotong dan dapat jatuh } \\
\text { kedalam wadah. }\end{array}$ \\
\hline $\mathbf{3 0}$ Detik & $0,5 \mathrm{Kg}$ & $\begin{array}{l}\text { Bagian sisi kanan dan kiri adonan dapat } \\
\text { terpotong dan jatuh kedalam wadah }\end{array}$ \\
\hline $\mathbf{3 0}$ Detik & $1 \mathrm{Kg}$ & $\begin{array}{l}\text { Adonan terpotong namun tidak dapat } \\
\text { jatuh kedalam wadah. }\end{array}$ \\
\hline
\end{tabular}

\section{SIMPULAN}

Berdasarkan hasil percobaan dan pembahasan yang dilakukan, dapat diambil beberapa kesimpulan:

a. Pembuatan mesin ini melibatkan beberapa mahasiswa tugas akhir untuk meningkatkan kemampuan atas keilmuan yang di peroleh mahasiswa selama kuliah.

b. Proses pemotongan pantiaw menghasilkan pemotongan yang seragam dengan lebar potongan $7 \mathrm{~mm}$ dengan kemampuan $0.5 \mathrm{~kg}$.

c. Kegagalan terjadi pada proses pemotongan $1 \mathrm{~kg}$ disebabkan oleh kawat pemotong yang kendor akibat tekanan.

d. Perlu adanya pengantian dudukan kawat pemotong yang lebih kuat dan tidak mudah berputar ketika proses penekanan dilakukan.

e. Hasil pemotongan bisa menghasilkan potongan yang sesuai dengan permintaan konsumen dan sudah bisa dipasarkan. 


\section{DAFTAR PUSTAKA}

[1]. Perpustakaan Digital Budaya Indonesia, Pantiaw, diakses pada 4 Agustus 2017, Available : http://budaya-indonesia.org/pantiaw

[2]. Jitunews, Mengintip Cara Membuat Pantiaw, Kudapan Khas Bangka yang Tinggi Karbohidrat,. Diakses pada 10 Februari 2016, Available: http://www.jitunews.com/read/30618/ [Hal. : 4-5]

[3]. Tahta M, Ridho dan Sinto, Rancang Bangun Alat Pemotong Pantiaw Kapasitas 15 kg/jam, Bangka: Politeknik Manufaktur Negeri Bangka Belitung, 2013.

[4]. Harsokoesoemo, Darmawan, Pengantar Perancangan Teknik, Bandung: ITB, 2004.

[5]. Sularso and Suga K, Dasar Perancangan dan Pemilihan Elemen Mesin, Jakarta: Pradnya Paramita, 2004.

[6]. Harsokoesoemo, Pengantar Perancangan Teknik, Bandung: ITB, 2000. 